UDC 303.446.2:32-026.195

\title{
SOCIOCULTURAL INTERACTION
} UNDER GLOBAL POLITICAL TRANSFORMATIONS

\section{- Maryna Shevchenko ${ }^{1 a}$, Taras Lysenkoª}

${ }^{1} \mathrm{PhD}$ in Cultural Studies, Associate Professor,

ORCID: 0000-0003-0960-513X, e-mail: ua.kiev.marina@gmail.com,

${ }^{2}$ Assistant, ORCID: 0000-0002-4879-9646, e-mail: tarafey@ukr.net, aKyiv National University of Culture and Arts, 36 Ye. Konovaltsia St., Kyiv, 01133, Ukraine

\section{- For citation:}

Shevchenko, M., \& Lysenko, T. (2021). Sociocultural Interaction Under Global Political Transformations. Issues in Cultural Studies, (38), 334-342. doi: https://doi.org/10.31866/24101311.38.2021.247178.

\section{- Abstract}

The purpose of the article is to analyse the basic mechanisms of the involved and complex process of sociocultural interaction under global political transformations. Research methodology. The interdisciplinary nature of the research issue involves the use of anthropological, historical and typological description; cultural-historical, comparative analysis; comparative studies and systematics. The structural and functional method is used to study the specifics of culture and politics; civilisational and comparative-historical methods are used to study the features of sociocultural interaction of society because of the transformation of the political system (institutions); a systematic approach provides a comprehensive analysis of the process of sociocultural globalisation. The scientific novelty lies in the fact that issues and features of sociocultural interaction in the context of globalisation are considered for the first time; two viewpoints of globalists, supporters of the development of global culture and anti-globalists who oppose cultural assimilation and cultural globalisation have been identified and characterised. Conclusions. It has been argued that the mechanisms of sociocultural globalisation must be based on the objectivity of global political transformations and the impossibility of stopping them. Sociocultural globalisation strengthens intercultural dialogue and interaction, the civil society's approach, expands the rights and freedoms of people, improves the quality and standard of living, and deepens understanding of specific features of other cultures, which harmonises the overall international relations system. The article shows that some skills development is important for more effective intercultural communication under globalisation and intensification of intercultural interaction. The development of such skills will allow representatives of different cultures and peoples to understand the similarities and differences between 
different cultures, enrich the achievements of other cultures' heritage, and navigate the cultural diversity of the modern world.

Keywords: sociocultural interaction; global political transformations; information and communication revolution; globalisation; intercultural communication; intercultural interaction; Westernisation; multiculturalism; acculturation

\section{Introduction}

Relevance of research topic. During the recent decades, the information and communicative revolution has been gaining momentum, due to which the sociocultural interaction between the different actors of international relations is intensifying and transforming. Strengthening globalisation processes and interaction between separate, previously isolated, nations and communities encourage scientists to find answers to questions concerning the further development of world culture and civilisation under conditions of scientific and technological progress and the rapid transformation of the system of international relations and the formation of a new global order.

Analysis of research and publications. The first attempt to explain the changes in the sociocultural environment due to globalisation processes was the scientific achievement of 1954 by American researchers D. Trager, E. Hall (1954) "Culture as Communication: Model and Analysis". In particular, the researchers first proposed for mass use a new scientific category - "intercultural communication", which, according to scientists, reflects a special branch of human relationships. Therefore, according to the scientific community, E. Hall is considered to be the founder of a separate scientific direction "intercultural communication".

E. Hall's ideas have been further developed in the following scientific fields, such as "cross-cultural interaction", "dialogue of cultures and civilisations", which also deal with the problem of intercultural communication in a globalised world. The ideas of intercultural and cross-cultural interaction became very popular, mainly in western scientific thought.

\section{Purpose of the article}

The article's main purpose is to analyse the general mechanisms of the compound and complex process of social and cultural globalisation.

\section{Main research material}

Sociocultural interaction of representatives of different peoples and social organisms significantly influences the content and direction of globalisation, as a leading trend of contemporary development. Under conditions of globalisation, migration processes are increasing, which leads to sociocultural "mixing" and strengthening intercultural communication. The policy of multiculturalism in the developed countries of the "West" is precisely aimed at the dialogue of cultures and their enrichment. It is believed that despite the numerous and large diasporas, representatives of different cultures and peoples are not assimilated and completely dissolved within the "Western" culture but rather enrich themselves and their own 
culture. However, it should also be noted that many scholars also talk about the failure of the policy of multiculturalism, the confrontation between the diaspora and the recipient country.

Thus, in the centre of the study of intercultural interaction under conditions of globalisation, there are various typologies of cultures. Investigating the interaction of numerous variegated cultures reveals their peculiarities, which should explain the scientific direction of "intercultural communication".

At present, we consider it appropriate to provide the author's definition of intercultural communication, which we understand as a qualitative and quantitative increase, thanks to the information and communication revolution and the strengthening of globalisation processes, all forms of communication between previously isolated peoples and societies, which leads to the transformation of intercultural interaction. In the process of intercultural communication, the enrichment of national cultures continues at the expense of other cultures. Cultural hybridisation and the weakening of the national cultures of periphery countries are taking place against the backdrop of the rapid spread of cultural norms of the core countries. However, due to the latest achievements in the information and science and technology spheres, representatives of disappearing cultures have the opportunity to bring their cultural achievements to the world community and always leave sociocultural information about themselves in electronic networks.

Enhancing globalisation processes substantially affects cultural genesis and mainly affects the social macro level, which is structured on the genesis of individual cultural forms. Today, under conditions of a demographic explosion and intensification of migration processes, cultural cultivation is also being transformed. The genesis of sociocultural forms under conditions of accelerated globalisation stimulates the development of global culture and strengthens the interconnections between local cultures and civilisations. The cultural genesis of the age of globalisation is influenced by informational and technological development, which fundamentally changes the society itself, which led to the emergence of concepts of a new, post-industrial society. However, one should consider that cultural studies under conditions of globalisation are controversial and uneven. Let us note the gap that deepens in the socio-economic and cultural development of the core and periphery countries. Under conditions of the information and communicative revolution, there is such a thing as information inequality.

Despite the digital, informational, social, etc., dependence among the participants in the world political process, the sociocultural genesis of the era of globalisation, which continues to contribute to the formation of the global community, which, according to the definition of British researcher W. Beck, is formed in the process of intercultural interaction. The scholar states the existence of the phenomenon of "identity blurring" and the transformation of the entire system of values. Sociocultural genesis contributes to the emergence of new social organisms, subcultures, groups of preferences protected by the policy of cultural pluralism. In the opinion of the scientist, that has along with positive features and a number of negative results, which are expressed, for example, in the loss of integrity, fragmentation of the cultural space into many elements of its constituents (Beck, 2001, p. 124). 
Sociocultural transformations of the age of globalisation, which have aggravated demographic and migration problems, have contributed to the scientific search for their distribution. There is the concept of "multiculturalism", which seeks to study the interaction of local cultures in a globalising environment and involves integration without assimilation. The focus of the concept of multiculturalism is the peaceful coexistence of local cultures, their interaction and mutual enrichment.

Thus, intercultural communication requires the presence of certain interests between representatives of various sociocultural organisms. Therefore, the dialogue of cultures and the policy of multiculturalism is a prerequisite for an effective and positive intercultural interaction under conditions of globalisation. The intercultural interaction of social communities promotes cultural homogenisation, "erosion" of national borders, standardisation. Under conditions of the Western civilisation, a one-sided process of spreading the "Western" sociocultural norms is often stated. This process has become categorical - "Westernisation". In the context of our study, we note that "Westernisation", according to the Webster Dictionary of English, means "conversion to or adoption of western traditions or techniques" (Merriam-Webster, n.d.).

Today, according to many researchers, "Westernisation" is not only one of the significant models of modernisation, but also part of any other models, since the borrowing of technical achievements, new social roles and political institutions that have been formed in the "West" inevitably leads to modernisation. At the initial stage, the process of Westernisation continues in any country in a not noticeable way. It is due to the peculiarity of the functioning of complex social systems. Initially, the Westernisation process in any country passes superficially due to the most general laws of the development of complex systems, including those which society is. It is due to the system's properties that retain a certain continuity and have some resistance to the impact of other cultures at the initial stage.

By studying such an important issue as intercultural communication in the context of globalisation, we consider it necessary to draw attention to the problem of acculturation, which in recent years has attracted the attention of many, Western scholars mostly. Thus, acculturation (lat. Acculturare - from the Latin Ad-pre, before and culture - education, development) - "the process of mutual influence of cultures (the exchange of cultural peculiarities), the perception of one nation in the whole or a part of the culture of another nation. At the same time, the original cultural models of one or both groups can be changed, but the groups are still different. It is necessary to distinguish between acculturation and assimilation, in which the loss of one language and culture by one people occurs in contact with another, more dominant. At the same time, undoubtedly, acculturation can be the first step on the way to complete assimilation" (Academic, n.d.).

A well-known Canadian researcher, J. Berry (2005), associates conflict and negotiation in the context of the sociocultural and psychological aspects that occur in the process of acculturation. According to the researcher, during acculturation, a group of people and their individual members participate in intercultural contacts, creating the potential for conflict and the need for negotiations to achieve adaptive results for both sides. Considering studies on acculturation, including strategies for accultation, the scientist states behavioural changes and acute stress. There is large 
group and individual differences in how contacting people in both groups discuss their acculturation (described in terms of integration, assimilation, division and marginalisation strategies), how they feel stress and how well they adapt in the psychological and sociocultural way. In general, those who support the integration strategy feel less stress and achieve better adaptation than those who prefer to marginalise; the result for those who pursue assimilation and separation is a feeling of greater stress and less adaptation. J. Berry (2005) believes that these data should change public policy and personal orientation toward further integration based on integration to improve intercultural communication (p. 697).

As an alternative, researchers from the University of California J. Zhang, J. M. Denis and K. Hausman (2018) argue that research on acculturation emphasises the cognitive and emotional benefits of bilingualism for immigrants. Parents, schools and peers play an important role in developing bilingualism. However, most studies focused on family socialisation for the development of linguistic heritage and the role of schools in acquiring English language skills. Scientists use a two-dimensional approach to study the impact of socialisation on both the family and community on the possession of young people in two languages. We have suggested that families and community members socialise ethnic practices and influence the level of knowledge of young adults and contribute to the study of English. The participants were 302 Latin American and Asian young people from immigrant families aged 18 to 25 who completed online surveys. Hierarchical regression analysis showed that both family and community were essential predictors of linguistic heritage, however, the family, but not the community, was a significant predictor of English proficiency. In addition, the analysis of moderation showed that these relations were stronger among Asian Americans than Latinos. Research shows the dual role of cultural family socialisation for both linguistic heritage and English proficiency. It also demonstrates that researchers should not forget about the importance of community in their own research. This study is an important step towards understanding social factors that support bilingualism (Zhang et al., 2018, p. 44).

Thus, globalisation of culture in the modern world is a complicated, dialectically controversial process in which contradictory tendencies of integration and disintegration, conflicts and cooperation, universalisation and particularisation do not exclude each other but are mutually complementary trends of development. That is why researchers often substantiate the opposite views on the essence of globalisation of culture and the tendencies of its implementation (M'iazova, 2008). The culture of any social organism is a complex system, the elements of which are traditional and innovative cultural forms, subcultures of various social communities, groups, ethnic groups, religious denominations, etc. In addition to certain features of unity, between the elements of the sociocultural system and between cultures as a whole, there are certain differences that, when interacting with subjects in the process of globalisation, can acquire different states: from integration (interpenetration) to conflict. In the process of globalisation objectively arise communication between representatives of different cultures (national and ethnic) or between subcultures. Researchers identify, as a rule, several basic ways of interaction of cultures, which result in or enrich the sociocultural experience of people and communities or aggravate ethnocultural con- 
tradictions. The main ones are acculturation, cultural expansion, cultural diffusion, synthesis of cultures etc. (Danylian \& Dzoban, 2017, p. 36).

Having considered the problems and peculiarities of sociocultural interaction under conditions of globalisation, we distinguish two positions - globalists, supporters of the development of global culture and anti-globalists that oppose cultural assimilation and cultural globalisation.

According to globalists, the enrichment of global culture at the expense of the local ones is an important factor in developing cultural diversity and heritage national cultures. Contemporary globalisation processes, primarily associated with scientific and technological progress and the information and communication revolution, transform sociocultural value orientations primarily through increased levels of freedom and the free choice of their own identities, sociocultural roles, and affiliation to certain sociocultural groups. Intercultural interaction goes beyond the usual sociocultural boundaries and acquires transnational characteristics. The accelerated development of local cultures and their attempts to declare themselves on a global level is stated by globalists. Globalists also reject the thesis of anti-globalists that the transparency of interstate borders leads to erosion of cultural identity and the loss of the heritage of local cultures. On the contrary, globalists are convinced that globalisation increases individual rights and freedoms and opens up new opportunities for both local cultures and for the global ones. An example of this can be the $\mathrm{EU}$, where the development and enrichment of European values and culture did not lead to loss of cultural diversity and heritage of national cultures.

However, from another point of view, the rapid development of global culture, the emergence of such concepts as Universalisation, Standardisation, Unification, Westernisation, etc., have led to the emergence of numerous anti-globalist movements that are opposed to supporters of the development of global culture and its enrichment through local cultures, which, in the belief of anti-globalists lose their inheritance and identity. Proceeding from this, several anti-globalists offer the conservation of local sociocultural achievements and the heritage of local cultures to prevent their assimilation. In the opinion of anti-globalists, the transparency of the interstate borders leads to the intensification of sociocultural interaction and increase the influence of the global popular culture, the dissemination of similar sociocultural norms, attitudes and images.

\section{Conclusions}

We believe that both sceptics and globalists' viewpoints have the right to exist despite their controversies and reflect the actual intercultural interaction processes in the international system's external environment. The consolidated position of the two vectors is that the information and communicative revolution has greatly influenced the intensification of intercultural cooperation. In this context, such notions like media culture and global culture appear, which in general is identified with the prevalence of predominantly Western cultural norms and attitudes. Although, we believe that media culture, or international culture, is a combination of many cultures and subcultures.

Intensification of intercultural interaction, based on respect and dialogue of cultures, promotes the development of society and individuals that are a part of it. In 
general, we note that intercultural interaction between individuals, local cultures and civilisations has a significant impact on the formation of international order and the transformation of the whole system of international relations. All actors in international relations, especially influential states, international and transnational organisations, should promote harmonious intercultural communication on the basis of planetary humanistic principles and the priority of human values. In general, the complexity of harmonising cultures within the framework of the contemporary system of international relations is based on their diversity and the desire of local cultures to preserve their specific features on the one hand and to use achievements and become part of global, mass culture on the other hand. Therefore, intercultural dialogue and the formation of models of intercultural interaction according to the globalisation processes of the present require the harmonious development of national cultures and the adoption of local cultures.

\section{- References}

Academic. (n.d.). Akkul'turatsiya [Acculturation]. Retrieved November 15, 2021, from https:// dic.academic.ru/dic.nsf/ruwiki/341498 [in Russian].

Beck, U. (2001). Chto takoye globalizatsiya? Oshibki globalizma — otvety na globalizatsiyu [What is Globalisation? The Errors of Globalism - Answers to Globalisation] (A. Grigorev, V. Sedelnik, Trans.; A. Filippov, Ed.). Progress-Traditsiya [in Russian].

Berry, J. (2005). Same Acculturation: Living successfully in two cultures // International Journal of Intercultural Relations, 29(6), 697-712 [in English].

Danylian, O. H., \& Dzoban, O. P. (2017). Hlobalizatsiia kultury: protyrichchia ta tendentsii rozvytku [Globalisation of culture: contradictions and trends]. The Bulletin of Yaroslav Mudryi National Law University. Series: Political, 2, 29-41 [in Ukrainian].

M'iazova, I. Yu. (2008). Mizhkulturna komunikatsiia: zmist, sutnist ta osoblyvosti proiavu (sotsialno-filosofskyi analiz) [Intercultural Communication: Content, Essence and Features of Manifestation (Socio-philosophical Analysis)] [Abstract of PhD Dissertation, Taras Shevchenko National University of Kyiv] [in Ukrainian].

Merriam-Webster. (n.d.). Westernization. In Merriam-Webster.com dictionary. Retrieved November 20, 2021, from https://www.merriam-webster.com/dictionary/ westernization [in English].

Trager, G., \& Hall, E. (1954). Culture and Communication: A Model and an Analysis. Explorations, 3, 157-249 [in English].

Zhang, J., Dennis, J. M., \& Houseman, Ch. (2018). The role of family and community bicultural socialisation in the bilingual proficiency of young immigrant adults. International Journal of Intercultural Relations, 67, 44-57. https://doi.org/10.1016/j. ijintrel.2018.09.003 [in English]. 


\title{
СОЦІОКУЛЬТУРНА ВЗАЄМОДІЯ В УМОВАХ ГЛОБАЛЬНИХ ПОЛІТИЧНИХ ТРАНСФОРМАЦІЙ
}

\author{
- Шевченко Марина Іванівна ${ }^{1 a}$, Лисенко Тарас Валерійович2а \\ ' ${ }^{1}$ Кандидат культурології, доцент, \\ ORCID: 0000-0003-0960-513X, e-mail: ua.kiev.marina@gmail.com, \\ ${ }^{2}$ Асистент, \\ ORCID: 0000-0002-4879-9646, e-mail: tarafey@ukr.net, \\ а Київський національний університет культури і мистецтв, \\ Київ, Україна
}

\section{- Анотація}

Мета статті - дослідити загальні механізми складного та комплексного процесу соціокультурної взаємодії в умовах глобальних політичних трансформацій. Методологія дослідження. Міждисциплінарний характер поставленої проблеми передбачає використання антропологічного, історико-типологічного опису; культурно-історичного, порівняльного аналізу; компаративістики та системності. Структурно-фрункціональний метод застосовано для дослідження специфріки культури та політики; цивілізаційний та порівняльно-історичний методи використано для вивчення особливостей соціокультурної взаємодії суспільства з огляду на трансформації політичної системи (інститутів); системний підхід дозволив здійснити різносторонній аналіз процесу соціокультурної глобалізації. Наукова новизна полягає в тому, що вперше розглянуто проблеми та особливості соціокультурної взаємодії в умовах глобалізації; виділено та схарактеризовано дві позиції - глобалістів, прихильників розвитку глобальної культури та антиглобалістів, які виступають проти культурної асиміляції та культурної глобалізації. Висновки. Доведено, що механізми соціокультурної глобалізації мають виходити з об'єктивності глобальних політичних трансформацій і неможливості їх зупинити. Соціокультурна глобалізація дозволяє посилити міжкультурний діалог і взаємодію, позиції громадянського суспільства, розширити права і свободи індивідуумів, підвищити якість і рівень життя, поглибити розуміння специфічних особливостей інших культур, що сприяє гармонізації всієї системи міжнародних відносин. Показано, що в умовах глобалізації та інтенсифікації міжкультурної взаємодії важливим є розвиток певних навичок для більш ефективної міжкультурної комунікації. Розвиток таких навичок дозволить представникам різних культур і народів зрозуміти схожість і відмінність між різними культурами, збагатитися досягненнями спадщини інших культур, орієнтуватися в культурному розмаїтті сучасного світу.

Ключові слова: соціокультурна взаємодія; глобальні політичні трансформації; інформаційно-комунікативна революція; глобалізація; міжкультурне спілкування; міжкультурна взаємодія; вестернізація; мультикультуралізм; акультурація 


\title{
- СОЦИОКУЛЬТУРНОЕ ВЗАИМОДЕЙСТВИЕ В УСЛОВИЯХ ГЛОБАЛЬНЫХ ПОЛИТИЧЕСКИХ ТРАНСФОРМАЦИЙ
}

\author{
- Шевченко Марина Ивановна ${ }^{1 a}$, Лысенко Тарас Валерьевич2а \\ - ${ }^{1}$ Кандидат культурологии, доцент, \\ ORCID: 0000-0003-0960-513X, e-mail: ua.kiev.marina@gmail.com, \\ ${ }^{2}$ Aссистент, \\ ORCID: 0000-0002-4879-9646, e-mail: tarafey@ukr.net, \\ а Киевский национальный университет культуры и искусств, \\ Киев, Украина
}

\section{- Аннотация}

Цель статьи - исследовать общие механизмы сложного и комплексного процесса социокультурного взаимодействия в условиях глобальных политических трансформаций. Методология исследования. Междисциплинарный характер поставленной проблемы предполагает использование антропологического, историко-типологического описания; культурно-исторического, сравнительного анализа; компаративистики и системности. Структурно-функциональный метод применен для исследования специфики культуры и политики; цивилизационный и сравнительно-исторический методы использованы для изучения особенностей социокультурного взаимодействия общества, учитывая трансформацииполитической системы (институтов); системныйподходпозволилпровести разносторонний анализ процесса социокультурной глобализации. Научная новизна состоит в том, что впервые рассмотрены проблемы и особенности социокультурного взаимодействия в условиях глобализации; выделены и охарактеризованы две позиции глобалистов, сторонников развития глобальной культуры и антиглобалистов, выступающих против культурной ассимиляции и культурной глобализации. Выводы. Доказано, что механизмысоциокультурнойглобализациидолжны исходить изобъективности глобальных политических трансформаций и невозможности их остановить. Социокультурная глобализация позволяет усилить межкультурный диалог и взаимодействие, позиции гражданского общества, расширить права и свободы индивидуумов, повысить качество и уровень жизни, углубить понимание специфических особенностей других культур, что способствует гармонизации всей системы международных отношений. Показано, что в условиях глобализации и интенсификации межкультурного взаимодействия важно развитие определенных навыков для более эффрективной межкультурной коммуникации. Развитие таких навыков позволит представителям разных культур и народов понять сходство и различие между разными культурами, обогатиться достижениями наследия других культур, ориентироваться в культурном многообразии современного мира.

Ключевые слова: социокультурное взаимодействие; глобальные политические трансформации; информационно-коммуникативная революция; глобализация; межкультурное общение; межкультурное взаимодействие; вестернизация; мультикультурализм; аккультурация 